\title{
Formulation of Biscuit Using Yellow Pumpkin Flour and The Addition of Coconut Flour as an Alternative for Complementary Feeding
}

\author{
DOI: $10.18196 / p t .2019 .092 .41-47$
}

\author{
Mauren Gita Miranti ${ }^{*}$ Dwi Kristiastuti, Endah Dwi Kusumasari \\ Department of Culinary Education, Faculty of Education, Surabaya State University, \\ Jl. Lidah Wetan, Surabaya 60213, Indonesia \\ *Corresponding author, email: maurenmiranti@unesa.ac.id
}

\begin{abstract}
Complementary food should be added to the diet of the babies in addition to breast milk from 6 months onward and the food should be sufficient for the baby's nutrition needs. Complementary feeding using baby biscuit made of yellow pumpkin flour and the addition of coconut flour is an effort to improve nutrition through local food diversification approach. The purpose of this study was to determine the best biscuit formulation and to test the physicochemical properties of the selected formula. This research used completely randomized experimental design consisting of four formulae of yellow pumpkin flour, i.e. $10 \%, 15 \%, 20 \%$ and 25\%. The results of organoleptic tests showed that the best formula of the biscuit as complementary food is $25 \%$ yellow pumpkin flour and $12 \%$ of coconut flour. Consumption of two servings of biscuits can meet the nutritional adequacy of the babies except calcium. The biscuits can be kept for 92 days 8 hours under open conditions. In addition, the biscuits have good physical properties in terms of water absorption and hardness. Keywords: Yellow pumpkin, Coconut, Biscuit, Complementary feeding
\end{abstract}

ABSTRAK

Makanan pelengkap perlu ditambahkan ke makanan bayi di samping ASI mulai 6 bulan dan makanan harus cukup untuk kebutuhan gizi bayi. Pemberian makanan pelengkap menggunakan biskuit bayi yang terbuat dari tepung labu kuning dan penambahan tepung kelapa merupakan upaya untuk meningkatkan gizi melalui pendekatan diversifikasi makanan lokal. Tujuan dari penelitian ini adalah untuk menentukan formulasi biskuit terbaik dan untuk menguji sifat fisikokimia dari formula yang dipilih. Penelitian ini menggunakan desain eksperimental acak lengkap yang terdiri dari empat formula tepung labu kuning, yaitu 10\%, 15\%, 20\% dan 25\%. Hasil tes organoleptik menunjukkan bahwa formula terbaik biskuit sebagai makanan pelengkap adalah 25\% tepung labu kuning dan 12\% tepung kelapa. Konsumsi dua porsi biskuit dapat memenuhi kecukupan gizi bayi kecuali kalsium. Biskuit dapat disimpan selama 92 hari 8 jam dalam kondisi terbuka. Selain itu, biskuit memiliki sifat fisik yang baik dalam hal penyerapan dan kekerasan air.

Kata Kunci: Labu kuning, Kelapa, Biskuit, Makanan komplementer

\section{INTRODUCTION}

Breast milk is the most essential food required by babies as it contains enough nutrients for growth. As the baby is 6 months old, however, breast milk is considered no longer sufficient to meet the growing energy and nutritional needs of the babies by $24-30 \%$ compared to the needs at the age of 3-5 months (World Health Organization, 2000 in Rustanti 2012). Therefore, babies can be introduced to additional foods as complementary food in addition to breast milk from six months onward.

According to the Regulation of the Ministry of Health of Indonesia number 224/MenKes/ SK/II/2007, complementary foods can be given in the form of biscuits with some characters, e.g. 10 gram-weight, $5-6 \mathrm{~cm}$ rounded diameter, sweet taste, and loved by babies. Biscuit is categorized as a snack that can be consumed by babies. In terms of the content, however, not all biscuits are sufficient for babies such as general biscuits in the market which have high carbohydrate and fat content but low in protein and provitamin A. Some essential nutrients such as protein and vitamin A should be consumed by babies and todlers, so it is necessary to substitute some of the ingredients with local ones (Denney, et.al, 2017). Protein for babies plays essential role in cell growth and maintenance, while vitamin A plays a role in the functioning of 
the immune system and protecting the integrity of epithelial cells of the skin layer, the surface of the eyes, the inside of the mouth, as well as the digestive and respiratory tracts (Parizkova, 2010). On the other hand, vitamin A deficiency is one of four major nutritional problems in Indonesia that should be addressed immediately because vitamin $A$ is an essential nutrient for humans and as many as three million children are blind due to vitamin A deficiency.

Careful selection of ingredients for complementary food is important to meet these requirements. In general, biscuits are made from a mixture of wheat flour, skim milk, refined sugar, and vegetable oil. To increase the nutrient content, these substances can be substituted by alternative food sources of protein and vitamin $\mathrm{A}$. One of the alternative vitamin A sources is yellow pumpkin (Cucurbita moschata), local food containing high beta-carotene at 1,569 $\mu \mathrm{g} / 100 \mathrm{~g}$. Yellow pumpkin can be processed into flour, so it can be used as a ingredient of complementary food. In addition, the protein contained in yellow pumpkin flour has 99\% digestibility thus it is suitable for baby (Sari etal., 2017). Based on the physical properties, the complementary food should not be too condensed in order to keep the baby's stomach with a small capacity not being full of less nutritious substances (Larasati et al., 2008).

In addition to nutrition, the flavor of the complementary baby biscuit should be considered. Adding coconut flour to the biscuits may provide the natural savory flavor the children love. As stated by Setiawati et al. (2015), the braided coconut can be used as an additional ingredient for cooking. Coconut can help control and confuse obesity of the children because it contains high dietary fiber (Trinidad et al., 2002) and high cellulose which contributes to the physiology of the body. Cellulose is a food fiber that cannot be digested by digestive enzymes. Based on this background, the research was conducted to find the best formula of complementary biscuits of milk made of arrowroot flour, yellow pumpkin flour, and coconut flour addition and its effect on the content of beta carotene, physicochemical characteristics and the acceptance of the biscuit.

\section{MATERIALS AND METHODS}

Material

The materials used in this research were collected from different markets, i.e. yellow pumpkin from Mangga 2 market; coconut from Wonokromo Market; and arrow root flour from Malang. Other materials were 'Blueband' brand margarine, refined sugar, full cream milk and egg obtained from eight different shops in Surabaya. The tools used in the manufacture of the product were tray made of plastics, slicer, blender, 80 mesh sieve, digital scales, mixer, spatula, stainless basin, spoon, knife, baking sheet, oven, syringe, and plastic triangle.

\section{Experimental Design}

The experimental design used in this study was completely randomized design. The factors used in this research are the addition of yellow pumpkin flour and coconut flour in biscuit dough, consisting of limousine level that is the addition of torbangun flour by $0 \%, 10 \%, 15 \%, 20 \%$ and $25 \%$ of the total combination of flour used in the biscuits with two cookies making periods as a group.

\section{Stages of research}

This research was conducted with several steps as following:

\section{Biscuit Formulation}

The addition of yellow pumpkin flourwas based on the ratio added to the formula. The formulas were labeled as F1 (with the addition ratio of $10 \%$ ), 
F2 (15\%), F3 (20\%) and F4 (25\%) which was based on the biscuit claims as a source of micronutrients. Based on the regulation by Food and Drug Supervisory Agency (BPOM), a food product in solid form should contain at least $15 \%$ nutritional adequacy rate of micronutrients to be referred to as a source of micronutrients.

\section{Material Preparation}

Yellow Pumpkin flour in this research was made by using convection oven method (Norfezah, 2013). The pumpkin was peeled and the seeds were removed. After that, the yellow pumpkin was washed with clean water before being sliced about1-2 mm large and dried by using an oven with the temperature of 600C (Usha et al., 2010; Cerniauskiene et al., 2014). The dried pumpkin was then milled into flour using blender and the flour was filteredusing80 mesh sievesto obtain uniform sized flour (Pongjanta et al., 2006; Nguyen et al., 2018). After obtaining yellow pumpkin flour, the flour was analyzed in terms of water content, total carotene, protein content, fat, carbohydrate, crude fiber and vitamin A.

For prepare Coconut Flour, Old coconuts were peeled to remove its skin and the brown portion was removed by scrapping it off. The coconuts were deshelled into pieces by grater. The powder was then steamed and dried by roasting technique using skillet with a small fire and consistent stirring.

After all material had been prepared, the biscuit production were started. Margarine was mixed with refined sugar and salt with a mixer. Egg yolk was added into the mixture and shaken until they were blended well. The wheat flour, yellow pumpkin flour, coconut flour, milk and baking powder were added and mixed well. The mixture then was put into triangle plastic then the dough inside the plastic was spread on a baking sheet, and put in oven with temperature of $1600 \mathrm{C}$ for 30 minutes.

\section{Physical and Chemical Analysis of Biscuits}

Organoleptic tests included: shape, texture, taste, expiration (regulation by the Ministry of Health number 224/Menkes/II/2007), color and appearance, aroma, receptivity and homogeneity (Asngari, 2016). Physical analysis included: hardness test and water activity test (aw). Chemical analysis included: Energy, Protein, Carbohydrate, Fat, Fiber (D. Pereira, et.al, 2013), water, ash, Vitamin A, and Beta-Carotene.

\section{RESULTS AND DISCUSSION}

The addition of yellow pumpkin flour was based on the ratio of yellow pumpkin flour to coconut flour. For example, in F1 (10\%) formula, the addition of yellow pumpkin flour and coconut flour was $10 \%$ of added wheat flour $(125 \mathrm{~g})$, which was 12.5 g. Likewise, in F2 (15\%), F3 (20\%) and F4 (25\%), the addition of yellow pumpkin and coconut flour were $18.75 \mathrm{~g}, 25 \mathrm{~g}$ and $31.25 \mathrm{~g}$, respectively. The determination of F1 (10\%), F2 (15\%), F3 (20\%) and F4 (25\%) formula was based on biscuit claims as a source of micronutrients. The regulation by Food and Drugs Supervisory Agency in 2003 states that a food product in solid form should contain at least $15 \%$ nutritional adequacy $(\mathrm{AKG})$ of micronutrients to be referred to as a source of micronutrients. Please note that the determination of the lower dose of formulation (F1

Table 1. Nutritional value of yellow pumpkin flour and coconut flour per $100 \mathrm{~g}$

\begin{tabular}{lll}
\hline Nutrition Content & Yellow pumpkin flour & Coconut flour \\
\hline Rendement & $10.49 \%$ & - \\
Protein & $10.12 \%$ & $18.2 \%$ \\
Fat & $4.87 \%$ & $12.2 \%$ \\
Carbohydrate & $14.22 \%$ & $31.7 \%$ \\
Fiber & $10.28 \%$ & $20 \%$ \\
Water & $11.88 \%$ & $6.2 \%$ \\
Ash & $7.73 \%$ & $4.9 \%$ \\
Betacarotene & $43.40 \mathrm{mg}$ & - \\
\hline
\end{tabular}

Source: BPKI 2017 
Table 2. Organoleptic compound test result of complementary babybiscuit made of yellow pumpkin flour and coconut flour

\begin{tabular}{lcccc}
\hline \multirow{2}{*}{ Components } & \multicolumn{4}{c}{ Treatments } \\
\cline { 2 - 5 } & F1 (10\%) & F2 (15\%) & F3 (20\%) & F4 (25\%) \\
\hline Form & 3.94 & 3.76 & 4.04 & 4.16 \\
Texture & 3.84 & 3.68 & 4.00 & 4.20 \\
Flavor & 3.52 & 4.00 & 3.86 & 4.16 \\
Aroma & 4.04 & 4.12 & 3.92 & 4.12 \\
Color & 3.96 & 4.20 & 4.12 & 4.04 \\
Receptivity (Preference) & 3.76 & 3.84 & 3.44 & 4.02 \\
Homogeneity & 4.04 & 3.44 & 4.02 & 4.00 \\
\hline
\end{tabular}

$=10 \%)$ was done using Microsoft Excel application with the calculation formula, in which $10 \%$ addition of yellow pumpkin flour and coconut flour will contribute nutrients by $15 \%$ AKG.

The use of coconut flour used in the study was $25 \%$ by weight of flour. The use of coconut flour for biscuit products produces a dough that does not easily clot. Coconut flour can be used as savory taste enhancer with low fat (10-15\%) to moderate fat $(16-22 \%)$. The nutritional value contained in yellow pumpkin flour and coconut flour is presented in Table 1.

From Table 1, it can be seen that yellow pumpkin flour has high nutritional value. This is in line with Thenir et al. (2017) stating that yellow pumpkin flour is mostly composed of carbohydrate as well as rich in fiber and vitamin A. In addition, yellow pumpkin flour has big potential to be utilized as raw materials for food industry.

\section{Organoleptic Test Scale Method}

The organoleptic test was performed by 25 panelists using the hedonic method which measurement is based on the level of fondness for the taste, color, aroma, and crunchiness of the biscuit. The results of the overall test of organoleptic test can be seen in the Table 2 .

The results of the organoleptic test of complementary baby biscuit made of of yellow pumpkin flour and coconut flour show that the best formula is $25 \%$ of yellow pumpkin flour. The use of yellow pumpkin flour is generally only used as much as $10 \%$ of the weight of wheat flour. This is in line with Sutardi (2009) and Tamba et al. (2014) mentioning that the maximum use of yellow pumpkin flour as substitution flour is $30 \%$. Otherwise, Pongjanta et.al (2006) stated that the use of substitution would be optimum for bakery product in a dose of $15-20 \%$. This is believed that the use of substitution flour in higher dose will result in soft and watery texture and lethargic taste.

\section{Storability}

Based on storability test conducted at East Java Research and Industrial Consultation Center in Surabaya, it was observed that the biscuits can be stored for 92 days 8 hours in open conditions (unpackaged). The storability of the biscuits is generally affected by fat and proteins substances that are easily damaged, as the air may make the cookies moisture increase, so that the water activity would increase too (Morais et al., 2018). Thus, it might be possible that the biscuits storability would be longer if they are stored in air-tight storage.

\section{Physical analysis}

The use of yellow pumpkin flour and coconut flour as substitution flour has increased the protein levels in the biscuits. The protein content in the biscuits affects the water absorption and the level of hardness of the biscuits (Sudha et al., 2007). Water absorption, one of the properties of protein hydration, is as defined as the ability of the protein to retain water in a food system. The higher the protein content in the biscuits, the higher the water absorption. Physical properties are related to the stir ability of the biscuits. Good quality biscuits should have high water absorption, so the biscuits are more durable when they are stored. The use of 
Table 3. Results of chemical analysis of complementary baby biscuit made of yellow pumpkin flour and coconut flour

\begin{tabular}{ll}
\hline Nuritional Content & Value \\
\hline Energy & $329.80 \mathrm{kal}$ \\
Protein & $11.95 \%$ \\
Fat & $7.81 \%$ \\
Carbohydrate & $51.60 \%$ \\
Food Fiber & $4.61 \%$ \\
Vitamin A & $44.90 \mathrm{mg} / 100 \mathrm{~g}$ \\
Vitamin C & $18.85 \mathrm{mg} / 100 \mathrm{~g}$ \\
Calcium & $86.50 \mathrm{mg} / 100 \mathrm{~g}$ \\
Phospor & $112.60 \mathrm{mg} / 100 \mathrm{~g}$ \\
Beta carotene & $162.15 \mathrm{mg} / 100 \mathrm{~g}$ \\
\hline
\end{tabular}

Source: BPKI 2017

yellow pumpkin flour and coconut flour is believed to increase the water absorption. Biscuits made using F4 formula with $11.95 \%$ protein content has the highest water absorption of $138.03 \%$.

The texture test in this study was intended to analyze the hardness level associated with crunchiness of the biscuits. The crunchiness of the biscuits will decrease as the increasing levels of hardness. Baby biscuits ideally have the level of hardness between 948-1196 gf and the texture should not be too hard yet not easily destroyed, so they can be used as finger food.

Biscuits made using F4 formula have the highest level of hardness of 1155.02 gf and still meet the ideal level of hardness for baby biscuits. The increase of protein levels may cause an imbalance of flour in water binding, resulting in imperfection of gelatinization process. This condition leads to the increase of product hardness. The number of broken biscuits tend to increase with the proportion of coconut flour, but it is likely to decrease as higher proportion of yellow pumpkin flour. Coconut flour contains a lot of fat. This is in line with the opinion of Lai and Lin (2006); Pareyt et al. (2010), and Devi et al. (2016) that the more the addition of fat, the broken biscuit tends to decrease. Based on the water absorption and the level of hardness, biscuits made using F4 formula have good physical properties as it is more durable when stored and not easily destroyed, so it can be suitably used as finger food for babies.

\section{Chemical analysis}

Chemical test is a test of the properties of a material that can be measured by certain methods and chemicals. The results of chemical test conducted in this research are presented in Table 3.

\section{Energy}

Energy of a food product is influenced by fat, protein, and carbohydrate content in the biscuits. Fat provides energy of $9 \mathrm{kcal}$, while protein and carbohydrates provide energy of $4 \mathrm{kcal}$. The fat content of all biscuits is higher than the specification of complementary baby biscuits ranging from 10 to $18 \%$. High level of fat in the biscuits is mainly due to the use of high dose of margarine which was $25.8 \%$ and the use of coconut flour as a natural savory taste. Fat serves as shortening to form the texture and taste of the biscuits so the lack of use of fat may lead to the harder texture of the biscuits. The use of margarine and egg yolk was in the same quantity for all formulations, so that the increase in fat content is influenced by the percentage of coconut flour. Biscuits made using F4 formula with the highest levels of fat and protein have the lowest carbohydrate content of $51.60 \%$. Despite the low the level of carbohydrate, the biscuit energy still meets the specifications of complementary baby biscuits of at least $400 \mathrm{kcal} / 100 \mathrm{~g}$ (Ministry of Health, 2007). Biscuits made using F4 formula have an energy of $329.80 \mathrm{kcal} / 100 \mathrm{~g}$. The energy per serving of $\mathrm{P} 3$ biscuits contributes to energy sufficiency of $40.63 \%$.

\section{Protein}

The protein content of all biscuits should meet the specifications of the baby's biscuits AS8-12\%. Protein content becomes serious concern as protein 
adequacy is still becoming major issue in determining food serving quantities, and in particular for babies, proteins are needed by babies for growth (Dewey, 2003). The serving quantity is determined from the biscuits made using F4formula with the protein content of $11.95 \%$. The serving quantity of biscuit made using F4 formula is to meet one third of the protein adequacy of $16 \mathrm{~g}$ is $50 \mathrm{~g}$ (2 pieces of biscuits).

\section{Fat}

Fat produced by the biscuit made using F4 formula is $7.81 \%$. This is in accordance with the requirement of fat in the complementary baby biscuits in which the fat content is not less than $1.5 \mathrm{~g} / 100 \mathrm{kcal}$ or $6 \mathrm{~g} / 100 \mathrm{~g}$. Fat content in the biscuits made using F4 formula is mainly sourced from the use of margarine and coconut flour.

\section{Vitamin A}

Vitamins are mandatory in any product utilized as complementary baby biscuits. One of them is the need of vitamin A (BSN, 2015). Biscuits made using F4formula contains $44.90 \mathrm{mg} / 100 \mathrm{~g}$ of vitamin A, which is mainly sourced from the use of yellow pumpkin flour as the material for the biscuits.

\section{Calcium}

The use of yellow pumpkin flour in formulating the biscuits can increase the calcium content by $62.9 \%$ in the product. Calcium content in biscuits made using F4 formula is $86.50 \mathrm{mg} / 100 \mathrm{~g}$; the value is still not in accordance with the required calcium for complementary baby biscuits in which the required level should be $200-400 \mathrm{mg} / 100 \mathrm{~g}$. The level of calcium in the biscuits was sourced from skim milk and egg yolks, while the bigger use of skim milk and overeating eggs may affect the physical quality of the biscuits.

\section{Beta-carotene}

Based on absorbance value, the value of beta-carotene content in biscuits dough is $172.50 \mathrm{mg} / 100 \mathrm{~g}$, while the value of beta-carotene in biscuit is $162.15 \mathrm{mg} / 100 \mathrm{~g}$. The retention of the carotene is 10.35 in which the carotene in the biscuits is smaller than in the dough which is mainly due to oxidation. This retention may lead to the degradation process of carotene which is caused by the combustion process to ripen the dough by $160 \mathrm{oC}$. The use of low temperatures with long heating time or high temperatures with short heating time may damage the carotene content (C. Penicaud, et al., 2010; Demiray, E. et al., 2013). Besides, the betacarotene resistance at heating temperature is also affected by the processing conditions, where long warming at $180^{\circ} \mathrm{C}$ (under oxygen-free conditions) causes little damage to beta-carotene (C.S. Boon, et al., 2010). However, the presence of the constituent components such as starch, fat, and water as well as mechanical mixing method will give possibility for oxygen and cause greater beta-carotene damage.

\section{CONCLUSION}

The best formula for complementary baby biscuits made of yellow pumpkin flour and coconut flour is $25 \%$ yellow pumpkin flour and $12 \%$ coconut flour. Consumption of two servings of biscuits made using F4 formula can meet the required nutritional adequacy of babies, except calcium content. The biscuits have good physical properties in terms of water absorption and hardness. The biscuits are recommended to be consumed as many as two serving if the baby consumes only breast milk.

\section{REFERENCE}

Asngari, Fu'ad Hasyim, Agustiana dan Hafni Rahmawati. 2016. Substitusi Tepung Labu Kuning (Cucurbits moschata, Durch) Terhadap Kandungan Vitamin A Dan Daya Terima Panelis Pada Sosis Ikan Nila (Oreochromis niloticus). Jurnal Fish Scientiae, Volume 6 Nomor 2, Desember 2016, hal 38-38. 
Badan Standar Nasional Indonesia. 2005. Makanan Pendamping Air Susu Ibu (breast milk complementary food) Bagian 2: Biskuit. SNI 01-7111.2-2005.

C. Penicaud, et.al. 2010. Degradation of B-Carotene During Fruit and Vegetable Processing or Storage: ReactionMechanisms And Kinetic Aspects: A Review. Fruits Journal, Vol. 66 (6) 417-440.

C. S. Boon, et.al. 2010. Factors Influencing the Chemical Stability of Carotenoids in Foods. Journal Food Science and Nutrition, Vol. 50 No. 6 June 2010, pp: 515-532.

Cerniauskiene, Judita, et.al. 2014. Pumpkin Fruit as a Source for Food Enrichment in Dietary Fiber. Not Bot Horti Agrobo, 2014 Volume 42, No, 1; pp: 19-23.

D. Pereira, et.al. 2013. Analysis of The Physical-Chemical and Sensorial Properties of Maria Type Cookies. Acta Chimica Slovaca, Vol. 6, No. 2, 2013, pp. 269-280.

Demiray, E.; Tulek, Y.; Yilmaz, Y. 2013. Degradation Kinetics of Lycopene, 6-carotene and Ascorbic Acid in Tomatoes During Hot Air Drying. LWT Food Sci. Technol Vol. 50 pp: 172-176.

Dewey,KG dan Brown. 2003. Update on technical issues concerning complementary feeding of young children in developing countries and implications for intervention programs. Food and Nutrition Bulletin the United Nations University 2003; 24:1.

Denney, Liya., et.al. 2017. Food Sources of Energy and Nutrients in Infants, Toddlers, and Young Children from the Mexican National Health and Nutrition Survey 2012. Article Nutrients 2017, 9, 494.

Devi, Amita and Khatkar. 2016. Physicochemical, Rheological and Functional Properties of Fata and Oils in Relation to Cookie Quality: A Review. Journal Food Sci Technol Vol. 53 No. 10 (October 2016), pp: 3633-3641.

Kementrian Kesehatan Republik Indonesia. 2007. Keputusan Mentri Kesehatan Republik Indonesia, Nomer: 224/Menkes/ SK/II/2007 tentang Spesifikasi teknis makanan Pendamping Air Susu Ibu (breast milk complementary food). Jakarta: Kementrian Kesehatan.

Lai HM, Lin TC. 2006.Bakery Products: Science and Technology. In: Hui YH, Corke HH, De Leyn HI, Nip WK, Cross N (eds) Bakery products: science and technology. Blackwell Publishing, Hoboken, pp 3-65.

Larasati D, Wahjuningsih SB, Pratiwi E. 2008. Kajian Formulation Bubur Bayi Instan Berbahan Dasar Pati Arrowroot (Maranta arundinaceae L) Sebagai Makanan Pendamping ASI Terhadap Sifat Fisik dan Organoleptik. Jurnal Teknologi Pangan dan Hasi Pertanian Vol. 5 No.2 Halaman 112-118. Semarang:Universitas Negeri Semarang.

M.L. Sudha, et.al. 2007. Fat Replacement in Soft Dough Biscuits: Its ImplicationsOn Dough Rheology and Biscuit Quality. Journal of Food Engineering Vol. 80 No. 3 (June 2007) pp: 922-930.

Morais, et. al,. 2018. Storage Stability of Sweet Biscuit Elaborated with Recovered Potato Starch from Effluent of Fries Industry. Food Sci. Technol, Campinas, 38(2), pp: 216-222, Apr.-June 2018.
Nguyen, Van Toan., et.al. 2018. Production of High-Qualiy Flour and The Made Biscuits from Pumpkin. International of Food Science and Nutritional Vol. 3(Issue 5) September 2018, pp. 157-166.

Pareyt B, Brijs K, Delcour J. 2010.Impact of Fat on Dough and Cookie Properties of Sugar-Snap Cookies. Cereal Chem 87:226-230.

Parízková J. 2010. Nutrition, Physical Activity, and Health in Early Life 2nd edition. USA: CRC Press.

Pongjanta, J., et.al. 2006. Utillization of Pumpkin Powder in Bakery Products. Songklanakarin J. Sci. Technology., 2006, 28(Suppl. 1) pp: 71-79.

Ranonto, Novrian Rasinta, Nuraeni, dan Abd Rahman Razak. 2010. Retensi Karoten Dalam Berbagai Produk Olahan Labu Kuning (Cucurbita moschata Durch). Online Jurnal of Natural Science Vol 4(1) :104-110 Maret 2015 ISSN: 2338-0950.

Rustanti dan Nurhidayati. 2012. Daya Terima Dan Kandungan Zat Gizi Biskuit Bayi Sebagai Makanan Pendamping ASI Dengan Substitusi Tepung Labu Kuning (Cucurbita moshchata) Dan Tepung Ikan Patin (Pangasius spp). Jurnal Aplikasi Teknologi Pangan Vol. 1 No. 3 Tahun 2012

Sari, Dewi Kartika., et.al. 2017. Characteristic Organoleptic Properties of Instant Baby Porridge High in Protein and Betacarotene. Pakistan Journal of Nutrition Vol. 16 No. 6, pp: 400-405.

Satriyanto, B., Widjanarko, SB., Yunianta. 2012. Stabilitas Warna Ekstrak Buah Merah Terhadap Pemanasan Sebagai Sumber Potensi Pigmen Alami. Jurnal Teknologi Pertanian. Vol. 13. No. 3: $157-168$.

Setiawati. Rahimsyah dan Ulyarti. 2015. Kajian Pembuatan Brownies Kaya Serat Dari Tepung Ampas Kelapa. Jurnal Penelitian Universitas Jambi Seri Sains Volume 17, Nomor 1, Hal. 84-89 Januari - Juni 2015 ISSN:0852-8349.

Sutardi., Agnes Murdiati., Yulianan Reni Swasti, Rusdin Rauf, Amaliah, Gardjito. 2009. Kajian Sifat Tepung dan Pengembangan Produk Umbi-umbian dan Sumber Karbohidrat Alternatif di DIY. DISAMPAIKAN PADA Workshop Pengembangan Pangan Lokal dan Pusat Kajian Makanan Tradisional 22-24 Juli 2009 di Bukit tinggi.

Tamba, Meskayani. Sentosa Ginting dan Lasma Nora Limbong. 2014. Pengaruh Substitusi Tepung Labu Kuning Pada Tepung Terigu Dan Konsentrasi Ragi Pada Pembuatan Donat. Jurnal Rekayasa Pangan dan Pertanian Bolume 2 No. 2 Tahun 2014.

Thenir, Riani. Ansharullah dan Djukran Wahab. 2017. Pengaruh Substitusi Tepung Labu Kuning (Cucurbita moschata) Terhadap Penilaian Organoleptik Dan Analisis Proksimat Kue Bolu Mangkok. Jurnal Sains dan Teknologi Pangan Vol. 2, No.1, P. 360 - 369, Th. 2017 ISSN: 2527-6271.

Trinidad et al. 2002. Coconut Flour from "Sapal"; A Promising Functional Food. Food and Nutrition Research Institute. Departement od Science and Technology, Manila.

Usha, et.al. 2010. Nutritional, Sensory and Physical Analysis of Pumpkin Flour Incorporated into Weaning Mix. Malaysian Journal of Nutrition Vol. 16 No. 3 December 2010 pp:378-387. 